\title{
Observations on some morphometric parameters and body weight of Fulani ecotype chicken sampled in Niger State, Nigeria
}

Yusuf, S., Ayoola, A. M., Falowo, O. A., Egena, S. S. A*., Adama, T. Z. and Banjo, A. A. Department of Animal Production, Federal University of Technology, P.M.B. 65, Minna, Niger State, Nigeria.

Abstract

*Corresponding author email: acheneje.egena@futminna.edu.ng

The study was conducted to evaluate morphometric traits (body length, body girth, wing length, Shank length, thigh length) and their association with body weight in Fulani Ecotype Chicken (FEC). Seventy-eight Fulani ecotype chickens were used for the experiment. They were fed compounded diet of $24 \% \mathrm{CP}$ and $3213 \mathrm{kcal} / \mathrm{kg}$ of metabolize energy for the first eight weeks, and 20\% CP and $2948 \mathrm{kcal} / \mathrm{kg}$ from 9-12 weeks. The birds were kept on deep litter throughout the experiment. Feed and water were offered ad libitum. Measurements were taken on body weight and five morphometric parameters at 4, 8 and 12 weeks of the experiment for analysis. The results showed that body weight had the highest coefficient of variation $(34.90 \%)$ at the end of the $4^{\text {th }}$ week, thigh length at the end of the $8^{\text {th }}$ week $(5.08 \%)$, and body girth at the end of the $12^{\text {th }}$ week (33.00\%). Correlation between body weight and the morphometric parameters evaluated were observed to be positive and significant $(p<0.05)$ except for correlation between body weight and thigh length at $4^{\text {th }}$ week. The direct effects of the parameters measured at 4,8 and 12 weeks were all significant $(p<0.05)$ except for thigh length at week 4. Conclusively, the study revealed the existence of a positive relationship between the measured morphometric traits and body weight of Fulani ecotype chicken at 4, 8 and 12 weeks of the experiment and that shank length could be used to predict body weight at 4, 8 and 12 weeks based on the high coefficient of determination $\left(R^{2}\right)$.

Keywords: Body weight, direct effect, indirect effect, Fulani ecotype chicken, morphometric traits.

\section{Introduction}

It is becoming evident that there is the need to diversify into the improvement and production of indigenous chicken breeds in order to play a role in reducing animal protein deficiency inherent in the populace. The indigenous chicken breeds are providers of food, income and even recreation for the populace and in view of this importance, it has become highly necessary to consolidate on ongoing improvement programmes on the indigenous chickens with the aim of improving their productive capacity and hence, enhance their contribution in alleviating the shortage of animal protein among the populace. Various ecotypes of the indigenous chickens abound in different agro climatic zones of the country. For instance, while Olori (1992) characterized the chickens into two groupings as forest and savannah or Yoruba and Fulani ecotypes; Momoh et al. (2007) grouped them into two categories based on their body size and weight as the heavy and light ecotype. The heavy ecotype (also referred to as the Fulani ecotype chicken) is predominantly found in the drier savannahs (guinea and sahel) and weigh between $0.9-2.5 \mathrm{~kg}$ at maturity. The light ecotype are all the chickens found in the swamp, rainforest and derived savannah agro-ecological zones with mature body weight ranging between $0.68-1.5 \mathrm{~kg}$. This Fulani ecotype chickens are reared mostly by the Fulani ethnic group. The genetic composition of this chicken is somehow 
unique because the conservative breeding practices of the Fulanis has ensured that to a large extent, the birds have been selected over several years, and have not been allowed to breed indiscriminately. The chickens have superior live weight than any of the other chicken ecotypes found within Nigeria (Olawunmi et al., 2008). Fayeye et al. (2005) opined that the Nigerian Fulani ecotype chicken has the genetic potential for improvement in growth and egg production. There is a relationship between body weight and morphometric characters in animals and because of this, body weight and body dimensions have been utilized as yardsticks for selection by local farmers and for research. The degree of correlation between morphometric characters and body weight depends largely on the species and breeds. Knowledge of this relationship could be used for the genetic improvement particularly of body weight because as Wiener (1994) reported, linear body dimension can be used as a way of estimating body weight. Linear body measurements reflect primarily the length of the long bones of the animal and when taken sequentially over a period of time, generally indicate the manner in which the animal's body is changing shape and by implication, this could be used as a yardstick for predicting live weight and carcass composition of the animal. Egena $e t$ al. (2014) for instance reported that body weight of male Nigerian indigenous chickens could be estimated via the use of body length, breast girth, wing length and shank thickness while Ige (2013) showed that relationship exist between body weight and linear body measurements in both Yoruba and Fulani ecotype chickens using correlation and regression model. There have been reports on the use of linear body measurements to predict body weights in chickens (Monsi, 1992; Gueye et al., 1998;
Momoh and Kershima, 2008). However, there is scarcity of information on the use of standardized partial regression coefficient (path analysis) to show this relationship in the Fulani ecotype chicken. The aim of the study therefore, is to evaluate some morphometric traits in Fulani ecotype chickens and their relationship with body weight using path analysis .

\section{Materials and methods Experimental location}

The study was carried out at the poultry farm of the Department of Animal Production, Federal University of Technology, Minna, Niger State, Nigeria. Niger State lies on latitude $10^{\circ} 00^{\prime}$ north and longitude $63^{\circ} 00^{\prime}$ east (http://zodml.org). It covers an area of $74,108.6$ square kilometers. The study area has two distinct seasons. (short wet season and a long dry season). Humidity is mostly low throughout the entire year, with mean relative humidity of between 40 to $70 \%$. The rains are convectional, mostly heavy and short in duration, characterized by frequent storms (Oyewole et al., 2014).

\section{Sourcing of eggs and incubation}

Three hundred and twenty Fulani ecotype chicken eggs were used for the experiment. The eggs were collected from different Fulani kraals, weighed and numbered. The eggs were incubated using an electric type incubator at a standard commercial hatchery. Out of 320 eggs set, 176 were found not to be fertile while the remaining 150 were fertile. The fertile eggs were transferred to the hatcher and only 78 eggs hatched.

\section{Management of birds}

The hatched chicks were weighed using an electronic scale (SF-400) and then transferred back to Minna where they were brooded together for a week. Wood shavings were used as the litter material throughout the 8-12 weeks of the experiment. Cleaned 


\section{Yusuf, Ayoola, Falowo, Egena, Adama and Banjo}

and disinfected feeders and drinkers were placed for easy access to the birds. Charcoal pot was used as a source of heat for the first 4 weeks which was then removed when the feathers were fully grown. They were fed in two phases of compounded feed: chick mash (0-8 weeks) and grower mash (9-12 weeks). The chick mash was formulated to provide $24 \% \mathrm{CP}$ and $3213 \mathrm{kcal} / \mathrm{kg}$ of metabolizable energy while the grower mash was to provide $20 \% \mathrm{CP}$ and 2948 $\mathrm{kcal} / \mathrm{kg}$ of metabolizable energy. Medications and proper vaccinations were given to the birds based on the recommendations of the Nigerian Veterinary Medical Association (NVMA) for the region.

\section{Parameters measured}

Data were collected from all the birds at 4,8 and 12 weeks of age, respectively. Data was collected on Body Weight (BW), Wing Length (WL), Body Length (BL), Breast Girth (BG), Shank Length (SL) and Thigh Length (TL) using the description given by FAO (2012).

\section{Statistical analysis}

Means, standard deviation and coefficients of variation of body measurements and blood parameters of the birds were computed using Microsoft Excel. The values of the parameters measured were transformed to generate the standardized version from the unstandardized variables using their means and standard deviations as described by Akintunde (2012). The standardized data were then subjected to regression and bivariate correlation analysis using SPSS (2006). The standardized partial regression coefficients called direct path coefficients were calculated thus:

$\sigma \mathrm{X}_{1} / \sigma \mathrm{Y}=\mathrm{P}_{1}{ }^{\prime}$, the path coefficient from $\mathrm{X}_{1}$ to $\mathrm{Y}$. $\sigma \mathrm{X}_{2} / \sigma \mathrm{Y}=\mathrm{P}_{2}{ }^{\prime}$, the path coefficient from $\mathrm{X}_{2}$ to $\mathrm{Y}$. $\sigma \mathrm{X}_{3} / \sigma \mathrm{Y}=\mathrm{P}_{3}{ }^{\prime}$, the path coefficient from $\mathrm{X}_{3}$ to $\mathrm{Y}$. $\sigma \mathrm{X}_{4} / \sigma \mathrm{Y}=\mathrm{P}_{4}$ ', the path coefficient from $\mathrm{X}_{4}$ to $\mathrm{Y}$. $\sigma \mathrm{X}_{5} / \sigma \mathrm{Y}=\mathrm{P}_{5}$, the path coefficient from $\mathrm{X}_{5}$ to $\mathrm{Y}$. Where $Y$ is the effect and $X_{1} X_{2}, X_{3} . X_{4}$ and $X_{5}$ are the causes. The indirect contributions of $\mathrm{X}_{1,} \mathrm{X}_{2}, \mathrm{X}_{3}, \mathrm{X}_{4}$ and $\mathrm{X}_{5}$ to $\mathrm{Y}$ were worked out as follows:

$\mathrm{Y}_{1}=\mathrm{P}_{1}+\mathrm{P}_{2} \mathrm{RX}_{1} \mathrm{X}_{2}+\mathrm{P}_{3} \mathrm{RX}_{1} \mathrm{X}_{3}+\mathrm{P}_{4} \mathrm{RX}_{1} \mathrm{X}_{4}+\mathrm{P}_{5} \mathrm{RX}_{1} \mathrm{X}_{5}$ $\mathrm{Y}_{2}=\mathrm{P}_{1} \mathrm{RX}_{1} \mathrm{X}_{2}+\mathrm{P}_{2}+\mathrm{P}_{3} \mathrm{RX}_{2} \mathrm{X}_{3}+\mathrm{P}_{4} \mathrm{RX}_{2} \mathrm{X}_{4}+\mathrm{P}_{5} \mathrm{RX}_{2} \mathrm{X}_{5}$ $\mathrm{Y}_{3}=\mathrm{P}_{1} \mathrm{RX}_{1} \mathrm{X}_{3}+\mathrm{P}_{2} \mathrm{RX}_{2} \mathrm{X}_{3}+\mathrm{P}_{3}+\mathrm{P}_{4} \mathrm{RX}_{3} \mathrm{X}_{4}+\mathrm{P}_{5} \mathrm{RX}_{3} \mathrm{X}_{5}$ $\mathrm{Y}_{4}=\mathrm{P}_{1} \mathrm{RX}_{1} \mathrm{X}_{4}+\mathrm{P}_{2} \mathrm{RX}_{2} \mathrm{X}_{4}+\mathrm{P}_{3} \mathrm{RX}_{3} \mathrm{X}_{4}+\mathrm{P}_{4}+\mathrm{P}_{5} \mathrm{RX}_{4} \mathrm{X}_{5}$ $\mathrm{Y}_{5}=\mathrm{P}_{1} \mathrm{RX}_{1} \mathrm{X}_{5}+\mathrm{P}_{2} \mathrm{RX}_{2} \mathrm{X}_{5}+\mathrm{P}_{3} \mathrm{RX}_{3} \mathrm{X}_{5}+\mathrm{P}_{4} \mathrm{RX}_{4} \mathrm{X}_{5}+\mathrm{P}_{5}$ Where $\mathrm{R}=$ correlation coefficient between the variables. The equations illustrate the splitting process for a 5 factor variables with one effect variable Y. The multiple linear regression model adopted for the study was; $\mathrm{Y}=\mathrm{a}+\mathrm{b}_{1} \mathrm{X}_{1}+\mathrm{b}_{2} \mathrm{X}_{2}+\mathrm{b}_{3} \mathrm{X}_{3}+-------------+\mathrm{bpXp}$ Where $\mathrm{Y}$ is the dependent or endogenous variable (body weight), $a$ is the intercept, $b$ is the regression coefficients and Xs are the independent or exogenous variables (wing length, body length, breast girth, shank length and thigh length).

\section{Results \\ Statistical summary of measured morphometric traits in Fulani ecotype chickens at 4, 8 and 12 weeks}

The statistical summary of the measured morphometric traits in Fulani ecotype chickens at the end of the $4^{\text {th }}, 8$ th and $12^{\text {th }}$ week is presented in Table 1. Body weight had the greatest variation at 4 week (34.90\%), followed by body girth (29.98\%). Moderate variation was observed for shank length $(16.78 \%)$ while the least variation was observed for thigh length (3.54\%). At the $8^{\text {th }}$ week, all the measured traits showed low coefficient of variation with body weight being the least varied $(0.89 \%)$. Body girth had greater variation at week 12 $(33.00 \%)$ while the least was observed for shank length $(0.49 \%)$. 
Morphometric parameters and body weight of Fulani ecotype chicken in Niger State, Nigeria

Table 1: Descriptive statistic of parameters measured in Fulani ecotype chickens at $4^{\text {th }}, 8^{\text {th }}$ and $12^{\text {th }}$ week of the experiment

\begin{tabular}{lcccccc}
\hline & BW $(\mathrm{g})$ & BL $(\mathrm{cm})$ & BG $(\mathrm{cm})$ & WL $(\mathrm{cm})$ & SL $(\mathrm{cm})$ & TL $(\mathrm{cm})$ \\
\hline Week 4 & & & & & & \\
Mean & 123.58 & 20.35 & 9.91 & 16.36 & 7.58 & 5.99 \\
SD & 43.13 & 4.38 & 2.97 & 4.24 & 1.27 & 0.21 \\
CV $(\%)$ & 34.90 & 21.55 & 29.98 & 25.94 & 16.78 & 3.54 \\
Week 8 & & & & & & \\
Mean & 318.29 & 26.71 & 15.49 & 24.23 & 11.34 & 8.35 \\
SD & 2.83 & 2.12 & 0.78 & 0.42 & 0.35 & 0.42 \\
CV (\%) & 0.89 & 7.94 & 5.02 & 1.75 & 3.12 & 5.08 \\
Week 12 & & & & & & \\
Mean & 537.68 & 34.23 & 15.86 & 30.73 & 14.00 & 11.15 \\
SD & 4.24 & 0.42 & 5.23 & 1.84 & 0.07 & 2.90 \\
CV $(\%)$ & 0.79 & 1.24 & 33.00 & 5.98 & 0.49 & 26.01 \\
\hline
\end{tabular}

$\mathrm{CV}=$ coefficient of variation, $\mathrm{SD}=$ standard deviation.

Correlation between body weight and linear body measurements of Fulani ecotype chickens at 4,8 and 12 weeks

The correlation between body weight and linear body measurement traits at the end of the $4^{\text {th }}$ week of the experiment is presented in Table 2. Body weight had significant and positive correlation with body length, body girth, wing length and shank length $(p<0.01 ; r=0.646-0.807)$. The correlation between body weight and thigh length was also positive but not significant ( $p>0.05$ ). Correlation between other parameters were significant $(\mathrm{p}<0.01)$ and positive except for thigh length which did not show any significant $(p>0.05)$ correlation with the other traits.

The correlation between body weight and linear body measurement traits at the end of the $8^{\text {th }}$ and $12^{\text {th }}$ week of the experiment are presented in Table 3. At 8 week of the experiment, positive and significant correlation were observed between body weight and body length, body girth, wing length, shank length and thigh length ( $p<0.01 ; r=0.574-0.834)$. Body weight had significant and positive correlation with body length, wing length, shank length, body girth and thigh length $(\mathrm{p}<0.01 ; \mathrm{r}=$ $0.474-0.871$ ) at 12 weeks.

Table 2: Correlation between body weight and morphological traits in Fulani ecotype chickens at 4 weeks

\begin{tabular}{|c|c|c|c|c|c|c|}
\hline & BW & $\mathrm{BL}$ & $\mathrm{BG}$ & WL & SL & $\mathrm{TL}$ \\
\hline \multicolumn{7}{|l|}{ BW } \\
\hline BL & $0.795 * *$ & & & & & \\
\hline $\mathrm{BG}$ & $0.646 * *$ & $0.552 * *$ & & & & \\
\hline WL & $0.77 * *$ & $0.679 * *$ & $0.599 * *$ & & & \\
\hline SL & $0.807 * *$ & $0.694 * *$ & $0.458 * *$ & $0.738 * *$ & & \\
\hline $\mathrm{TL}$ & 0.082 & -0.015 & 0.053 & 0.086 & 0.117 & \\
\hline
\end{tabular}


Yusuf, Ayoola, Falowo, Egena, Adama and Banjo

Table 3: Correlation between body weight and morphological traits in Fulani ecotype chickens at 8 and 12 weeks

\begin{tabular}{|c|c|c|c|c|c|c|}
\hline & BW & BL & BG & WL & SL & TL \\
\hline BW & & $0.804 * *$ & $0.474 *$ & $0.867^{* *} *$ & $0.871 * *$ & $0.736^{* *}$ \\
\hline $\mathrm{BL}$ & $0.678 * *$ & & $0.460 *$ & $0.670 * *$ & $0.785^{* * *}$ & $0.609 * *$ \\
\hline $\mathrm{BG}$ & $0.722 * *$ & $0.484 * *$ & & 0.282 & 0.338 & 0.0026 \\
\hline WL & $0.574 * *$ & 0.232 & $0.483 * *$ & & $0.782 * *$ & $0.667 * *$ \\
\hline SL & $0.834 * *$ & $0.585^{* *} *$ & $0.642 * *$ & $0.610 * *$ & & $0.702 * *$ \\
\hline $\mathrm{TL}$ & $0.809 * *$ & 0.365 & $0.557 * *$ & $0.603 * *$ & $0.692 * *$ & \\
\hline
\end{tabular}

Above diagonal is correlation at 12 weeks while correlation at 8 weeks is below the diagonal.

$* *=\mathbf{p}<0.01, \mathrm{BW}=$ body weight, $\mathrm{BL}=$ body length, $\mathrm{BG}=$ breast girth, $\mathrm{WL}=$ wing length, $\mathrm{SL}=$ shank length, $\mathrm{TL}=$ thigh length.

Predicting body weight from the measured morphometric traits of Fulani ecotype chicken at 4, 8 and 12 weeks

The regression between body weight and all the measured traits of Fulani ecotype chicken at the $4^{\text {th }}, 8^{\text {th }}$ and $12^{\text {th }}$ week of the experiment are presented in Table 4. The table shows the regression equations and the coefficient of determination $\left(\mathrm{R}^{2}\right)$ of all the traits with relation to body weight. At all the weeks $\left(4^{\text {th }}, 8^{\text {th }}\right.$ and $\left.12^{\text {th }}\right)$ shank length had the highest $\mathrm{R}^{2}$ values $(0.807,0.834$ and 0.871 , respectively) representing $80.7,83.4$ and $87.1 \%$ of the accounted variation for body weight in the chicken; it also had the lowest standard error of mean $(0.33,11.93$ and 10.34, respectively) among all the parameters, while thigh length $(0.082)$ at week 4 , wing length $(0.574)$ at week 8 and body girth (0.474) at week 12 had the least values.

Direct and indirect effects of body measurements on body weight in Fulani ecotype chickens

The direct and indirect effects of linear body measurements on body weight in Fulani ecotype chickens at week 4, 8 and 12 are presented in Table 5. The traits all made positive and significant $(\mathrm{p}<0.05)$ direct contributions to the body weight of the Fulani ecotype chickens with the exception of thigh length which had no significant $(p<0.05)$ direct contribution at week 4 .

Table 4: Predictive equations relating morphological traits in Fulani ecotype chickens to body weight at 4,8 and 12 weeks

\begin{tabular}{|c|c|c|c|}
\hline Trait & Regression equation & SEM & $\mathrm{R} 2$ \\
\hline \multicolumn{4}{|c|}{ Week 4} \\
\hline BL & $\mathrm{BW}=0.00000074+1.037 \mathrm{BL}$ & 0.34 & $0.759 *$ \\
\hline BG & $\mathrm{BW}=0.0000012+0.812 \mathrm{BG}$ & 0.42 & $0.646^{*}$ \\
\hline WL & $\mathrm{BW}=0.00000015+0.84 \mathrm{WL}$ & 0.35 & $0.770 *$ \\
\hline SL & $B W=0.0000011+1.0559 S L$ & $\mathbf{0 . 3 3}$ & $0.807 *$ \\
\hline TL & $\mathrm{BW}=0.0000010+0.006 \mathrm{TL}$ & 0.55 & 0.082 \\
\hline \multicolumn{4}{|c|}{ Week 8} \\
\hline BL & $\mathrm{BW}=0.0000220+8.495 \mathrm{BL}$ & 15.9 & $0.678 *$ \\
\hline BG & $\mathrm{BW}=0.0000500+8.139 \mathrm{BG}$ & 14.9 & $0.722 *$ \\
\hline WL & $\mathrm{BW}=0.2520000+3.398 \mathrm{WL}$ & 17.72 & $0.574 *$ \\
\hline SL & $\mathrm{BW}=0.0000560+5.873 \mathrm{SL}$ & 11.93 & $0.834 *$ \\
\hline TL & $\mathrm{BW}=0.0000120+6.789 \mathrm{TL}$ & 12.73 & $0.809 *$ \\
\hline \multicolumn{4}{|c|}{ 8. } \\
\hline BL & $\mathrm{BW}=0.0000067+2.583 \mathrm{BL}$ & 12.52 & $0.804 *$ \\
\hline BG & $\mathrm{BW}=0.000024+30.858 \mathrm{BG}$ & 18.55 & $0.474 *$ \\
\hline WL & $\mathrm{BW}=0.000016+12.447 \mathrm{WL}$ & 10.48 & $0.867 *$ \\
\hline SL & $\mathrm{BW}=0.000058+1.060 S L$ & 10.34 & $0.871 *$ \\
\hline $\mathrm{TL}$ & $\mathrm{BW}=0.0000074+28.631 \mathrm{TL}$ & 14.26 & $0.736^{*}$ \\
\hline
\end{tabular}


Morphometric parameters and body weight of Fulani ecotype chicken in Niger State, Nigeria

Table 5: Direct and indirect effects of body measurement traits measured on body weight in Fulani ecotype chickens at $4^{\text {th }}, 8^{\text {th }}$ week and $12^{\text {th }}$ week

\begin{tabular}{|c|c|c|c|c|c|c|}
\hline \multirow[b]{2}{*}{ Trait } & \multicolumn{6}{|c|}{ Indirect effects } \\
\hline & BL & BG & WL & SL & $\mathrm{TL}$ & Total \\
\hline \multicolumn{7}{|c|}{ Week 4} \\
\hline BL & 1.04* & 0.45 & 0.57 & 0.73 & 0.00 & 1.75 \\
\hline BG & 0.57 & 0.81* & 0.50 & 0.49 & 0.00 & 2.37 \\
\hline WL & 0.70 & 0.49 & 0.84* & 0.78 & 0.00 & 2.81 \\
\hline SL & 0.72 & 0.37 & 0.62 & 1.06* & 0.00 & 2.77 \\
\hline TL & 0.42 & 0.42 & 0.54 & 0.66 & $0.00 \mathrm{~ns}$ & 2.04 \\
\hline \multicolumn{7}{|c|}{ Week 8} \\
\hline BL & 8.49* & 3.94 & 0.79 & 3.44 & 2.48 & 10.65 \\
\hline BG & 4.11 & $8.14 *$ & 1.67 & 3.77 & 3.78 & 13.33 \\
\hline WL & 1.97 & 3.99 & 3.40* & 3.55 & 4.14 & 13.65 \\
\hline SL & 4.97 & 5.23 & 2.05 & $5.87 *$ & 4.70 & 16.95 \\
\hline TL & 3.10 & 4.53 & 2.07 & 4.06 & $6.79 *$ & 13.76 \\
\hline \multicolumn{7}{|c|}{ Week 12} \\
\hline BL & $2.58 *$ & 14.20 & 8.34 & 0.83 & 17.44 & 40.81 \\
\hline $\mathrm{BG}$ & 1.19 & 30.86* & 3.52 & 0.36 & 0.74 & 5.81 \\
\hline WL & 1.73 & 8.73 & $12.45^{*}$ & 0.83 & 19.1 & 30.39 \\
\hline SL & 2.03 & 10.43 & 9.73 & 1.06* & 20.1 & 42.29 \\
\hline TL & 1.57 & 0.80 & 8.30 & 0.74 & $28.63 *$ & 11.41 \\
\hline
\end{tabular}

Shank length had the greatest direct effect on body weight (1.06) while the least was made by thigh length (0.00). The indirect effect was mostly through the shank acting with the other body measurements. At week 8 and 12 of the experiment, all the traits made positive direct contribution $(\mathrm{p}<0.05)$ to the body weight of the chickens. The indirect effects were mostly through body girth (at week 8) and thigh length (at week 12). With the exception of body girth and thigh length (at week 12), all the total indirect effects were observed to be greater than the individual direct effects.

\section{Discussion}

The high coefficient of variation observed for body weight (at week 4), body length (at week 8) and body girth (at week 12) are all indicative of the suitability of these traits being used as candidates for the genetic improvement of the Fulani ecotype chickens. This is because the traits were the most varied meaning across the chickens, the greatest genetic difference was observed for the traits at the various weeks of study. Genetic differences be it within or without an animal breed, are raw materials for selection and improvement. The implication of the result is that, at week 4 , the body weight measurements can be used to select birds that will likely grow faster; same applies for body length at week 8 , and body girth at week 12. This is more possible, considering the positive and significant correlation observed between body weight and the traits concern (Table 2). Working with adult indigenous chickens (irrespective of their ecotype in Niger State), Egena et al. (2014) observed higher variation in shank length (male), and body weight of the female.

The strong and positive nature of the correlation coefficients between body 


\section{Yusuf, Ayoola, Falowo, Egena, Adama and Banjo}

weight and the morphometric traits (excepting thigh length at week 4) reflects the existence of a relationship between them implying that as any of the traits is improved, it will correspondingly lead to an improvement in the other particularly as the sign of the relationship is not negative. (Wolanski et al. 2006) reported that growth in animals could be predicted or evaluated from the component parts of the body. This makes the body parts veritable tools useable in estimating body weight in animals. Egena et al. (2014) had opined that body weight could be estimated via the use of body length, breast girth, wing length and shank thickness in male indigenous Nigerian chickens because of the positive correlation existing between them. Other authors had reported on high correlation between body weight and morphometric traits in indigenous chickens of Senegal (Gueye et al., 1998); in Jinghai yellow chickens of China (Yang et al., 2006); and in Gaga chickens of Indonesia (Sri Rachma et al., 2013).

In trying to arrive at the best body part that can best be used for predictive purpose of body weight, shank length was observed to be the best at week 4,8 and 12 , respectively and possibly, the best single predictor of body weight. This is based on the high $\mathrm{R}^{2}$ values obtained for the three equations generated (0.807, 0.834 and 0.871). These $\mathrm{R}^{2}$ values indicate that shank length acting alone, accounted for 80.7, 83.4 and $87.1 \%$ of the total variance leading to body weight of the chickens at week 4,8 and 12 , respectively. Another interesting observation is the gradual increase observed in the $\mathrm{R}^{2}$ value with increase in the age of the birds; a 3.35 and $4.44 \%$ increase in the contribution of shank length was noticed as the birds age from 4 to 8 weeks, and from 8 to 12 weeks, respectively. In genetic terms, this somewhat marginal increase could greatly impact on the body weight of the Fulani ecotype chicken. Anebi (2010) reported shank length to be the best predictor of body weight in the domestic pigeon in Nigeria. Bokhari Squab Farm (2002) and Gambo et al. (2014) also reported that shank length can serve as a reliable index of body weight during most of the growing periods of pigeons, and in Coturnix quail; results in the Fulani ecotype chicken seems to be pointing in the same direction.

The direct effects of all the morphometric traits were observed to be significant and also positive but for thigh length at week 4 . This means that the traits, whose direct effects were positive and significant directly contributed to the body weight at week 4,8 and 12 , respectively. The combination of the indirect effects of the morphometric traits was observed however to be greater than the individual direct effects. This could mean that when the traits are combined in a selection process, possibly greater improvement of the chicken's body weight will be achieved than when they are used alone. However at week 12, body girth and thigh length contributed more to the body weight due to their quite high direct effects. This may possibly be because these parts contributed most to body weight of the chickens due to their relatively large size when compared to the other body parts. The breast girth also encompasses some of the breast region of the carcass; a choice part of the carcass of economic importance to consumers. Egena et al. (2014) in their work with indigenous chickens of Niger State reported that body girth (in female) and shank length (in males) did not make any significant direct contribution to the body weight of the chickens. The difference observed between both works could be due to the fact that only a particular chicken type (Fulani ecotype) was used in the present 
study while in the previous study; all the indigenous chickens' breeds in the State were used.

\section{Conclusion}

Body length and body girth could be selected as candidate traits in the improvement of body weight of the Fulani ecotype chickens. Positive and significant correlation coefficients were observed between body weight and the morphometric traits evaluated at week 4,8 and 12 except for thigh length which was positive but insignificant at week 4. Shank length is the best predictor of body weight of the Fulani ecotype chickens due to the high $\mathrm{R}^{2}$ values observed at week 4,8 and 12. This led to the development of the following predictive equations: $\mathrm{BW}=$ $0.0000011+1.0559 \mathrm{SL}$ (at week 4$), \mathrm{BW}=$ $0.0000560+5.873 \mathrm{SL}$ (at week 8 ), and BW= $0.000058+1.060 \mathrm{SL}$ (at week 12), respectively. It is the intention of the authors to utilize these equations in subsequent generations of the Fulani ecotype chickens used in the present study to ascertain their suitability as selection tools in the improvement of body weight of the Fulani ecotype chickens. Shank length (at week 4), body length (at week 8) and body girth (at week 12) made the greatest direct contribution to the body weight of the Fulani ecotype chickens. When combined, the indirect effects were observed to be greater than the individual direct effects (excepting body girth and thigh length at week 12).

\section{Reference}

Akintunde, A. S. 2012. Path analysis step by step using Excel. Journal of Technical Science and Technologies 1(1): 9-15.

Anebi, P. E. 2010. Genetic analysis of a flock of domestic Pigeons
(Columba via domestica). MSc. Thesis, Department of Animal Breeding and Physiology, University of Agriculture, Makurdi. Benue State, Nigeria. 68 pp.

Bokhari Squab Farm 2002. Squabbling Pigeons Breeders hand book. Retrieved on October 10, 2017, f $\quad \mathrm{r} \quad \mathrm{o} \quad \mathrm{m}$ http//www.bokhari.com/handboo khtml

Egena, S. S. A., Ijaiya, A. T. and Kolawole, R. 2014. An assessment of the relationship between body weight and body measurements of indigenous Nigeria chickens (Gallus Gallus domesticus) using path coefficient analysis. Livestock Research for Rural Development. Volume 26, Article \#51. Retrieved October 9, 2017, f $\quad \mathrm{r} \quad \mathrm{o} \quad \mathrm{m}$ http://www.lrrd.org/lrrd26/3/egen 26051.htm

FAO 2012. Phenotypic characterization of animal genetic resources, FAO Animal Production and Health Guidelines, 11, Rome.

Fayeye, T. R., Adeshiyan, A. B. and Olugbami, A. A. 2005. Egg traits, hatchability and early growth performance of the Fulaniecotype chicken. Livestock Research for Rural Development. Volume 17, Article \#94. Retrieved October 9, 2017, from http://www.lrrd.org/lrrd17/8/faye 17094.htm

Gambo, D., Momoh, O. M., Dim, N. I. and Kosshak, A. S. 2014. Body parameters and prediction of body weight from linear body measurements in Coturnix quail. Livestock Research for Rural 


\section{Yusuf, Ayoola, Falowo, Egena, Adama and Banjo}

Development. Volume 26, Article \#110. Retrieved October 9, 2017, $\begin{array}{llll}\mathrm{f} & \mathrm{r} & \mathrm{o} & \mathrm{m}\end{array}$ http://www.lrrd.org/lrrd26/6/dau d26110.html

Gueye, E. F., Ndiaye, A. and Branckaert, R. D.S. 1998. Prediction of body weight on the basis of body measurements in mature indigenous chickens in Senegal. Livestock Research for Rural Development. Volume 10, Article \#28. Retrieved October 9, 2017, $\begin{array}{llll}\mathrm{f} & \mathrm{r} & \mathrm{o} & \mathrm{m}\end{array}$ http://www.lrrd.org/lrrd10/3/sen e103.htm

http://zodml.org/nigeria/geography/niger $\% 20$ state

Ige, A. O. 2013. Estimation of genetic parameter in Yoruba and Fulani ecotypes indigenous

chickens of Nigeria . Transnational Journal of Science and Technology, 3(10): 1-6.

Momoh, O. M. and Kershima, D. E. 2008. Linear body measurements as predictors of body weight in Nigerian local chickens. Journal of Agricultural Sciences, Science, Environment and Technology (ASSET), Series A 8(2): 206-212.

Momoh, O. M., Ehiobu, N. G. and Nwosu, C. C. 2007. Egg production of two Nigerian local

chicken ecotypes under improved management. Proceedings 32nd Annual conference of Nigerian Society for Animal Production. $18^{\text {th }}-22^{\text {nd }}$, March. Calabar, Cross River State, Nigeria. Pp: 278281.

Monsi, A. 1992. Appraisal of interrelationships among live measurements at different ages in meat type chickens. Nigerian Journal of Animal Production 19(1\&2): 15-24.

Olawumi, O. O., Salako, A. E., Afuwape, A. A. 2008. Morphometric differentiation and assessment of function of the Fulani and young ecotype indigenous chickens of

Nigeria. International Journal of Morphology 26(4): 975-980.

Olori, V. E. 1992. An evaluation of two ecotypes of the Nigerian Indigenous chicken. M.Sc.

Thesis, Obafemi Awolowo University, Ile Ife.

Oyewole, J. A., Thompson, A. M., Akinpelu, J. A. and Jegede, $O$. O.2014. Variation of rainfall and humidity in Nigeria. Journal of Environment and Earth Science 4(2): 29-37.

Sri Rachma, A. B., Hiroshi, H., Muh. Ihsan, A. D., Lellah, R. and Kusumandari, I. P. 2013. Study of body dimension of Gaga' chicken, germ plasm of local chicken from south SulawesiIndonesia. International Journal of Plant, Animal and Environmental Studies 3(4): 204209.

SPSS 2001. Statistical Package for Social Sciences. SPSS Inc., 444 Michigan Avenue, Chicago, IL60611.

Wiener, G. 1994. Animal breeding. Tropical Agriculturist. Macmillian Education Limited, London.

Wolanski, N. J., Renema, R.A., Robinson, F. E., Carney, V. L. and Fanchert, B. I. 2006 . Relationship between chick 
Morphometric parameters and body weight of Fulani ecotype chicken in Niger State, Nigeria

conformation and quality measures with early growth traits in males of eight selected pure or commercial broiler breeder strains. Poultry Science 85: 14901497.
Yang, Y., Mekki, D. M., Lu, S. J., Yu, J. H., Wang, L. Y., Wang, J. Y., Xie, K. Z. and Dai, G. J. 2006. Canonical correlation analysis of body weight, body measurements and carcass characteristics of Jinghai Yellow chicken. Journal of Animal and Veterinary Advances 5: $\quad 980-984$. http://medwelljournals.com/abstr act/?doi=javaa.2006.980.984

Received: $10^{\text {th }}$ May, 2017

Accepted:27 ${ }^{\text {th }}$ September, 2017 